\title{
Evaluasi Ketepatan Antibiotik pada Pasien Sepsis
}

\section{Evaluation of Antibiotic Therapy in Sepsis Patients}

\author{
Ambar Yunita Nugraheni ${ }^{1 *}$, Mahyastuty Shintya Putri Utami ${ }^{1}$, Adi Yusron Saputro ${ }^{1}$ \\ ${ }^{1}$ Fakultas Farmasi, Universitas Muhammadiyah Surakarta, Jl. A. Yani, Kartasura, Sukoharjo, Indonesia \\ *E-mail: ayn122@ums.ac.id
}

Received: 13 Desember 2021; Accepted: 30 Desember 2021; Published: 31 Desember 2021

\begin{abstract}
Abstrak
Pemberian antibiotik dini secara intravena ialah salah satu tata laksana mendasar pada sepsis. Pemberian antibiotik yang tidak tepat pada pasien sepsis berdampak terhadap mortalitas dan memperpanjang perawatan. Tujuan dari penelitian ini ialah untuk mengevaluasi ketepatan terapi antibiotik pada pasien sepsis rawat inap rumah sakit di Jawa Tengah berdasarkan parameter tepat indikasi, tepat pasien, tepat obat, dan tepat dosis. Penelitian dilakukan secara observasional. Pengambilan data dilakukan secara retrospektif dan dianalisis secara deskriptif. Pengambilan sampel dilakukan secara purposive sampling. Kriteria inklusi ialah pasien rawat inap dengan diagnosis sepsis yang mendapatkan terapi antibiotik serta memiliki catatan rekam medis lengkap. Kriteria eksklusi ialah pasien sepsis yang meninggal dunia. Antibiotik dianalisis menggunakan pedoman DIH 25 ${ }^{\text {th }}$ edition 2016, IONI 2014, Tata Laksana Sepsis Pada Anak IDAI 2016, Neofax 2014, Kepmenkes PNPK Tata Laksana Sepsis 2017, PPK rumah sakit, dan SHC Antimicrobial Dosing 2017. Berdasarkan data 108 pasien yang memenuhi kriteria inklusi didapatkan hasil tepat indikasi sebanyak 100\%, tepat pasien sebanyak $97,22 \%$, tepat obat sebanyak 90,74\%, dan tepat dosis sebanyak 48,15\%. Antibiotik yang paling banyak digunakan yaitu kombinasi ampicillin dengan gentamicin $(41,67 \%)$, sedangkan untuk antibiotik tunggal yaitu ceftriaxone (12,96\%).
\end{abstract}

Kata Kunci: antibiotik, sepsis, rawat inap

\begin{abstract}
The administration of early intravenous antibiotics was one of the fundamental procedures in sepsis. Inappropriate of antibiotics in septic patients has an impact on mortality and prolongs treatment. The purpose of this study was to evaluate the appropriateness of antibiotics therapy in hospitalized sepsis patients in Central Java based on the parameters right indication, right patient, right drug, and the right dose. This study was observational. Data collected retrospectively and analyzed descriptively. Sampling was done by purposive sampling. The inclusion criteria were inpatients diagnosed with sepsis who received antibiotics therapy with complete medical record data. The exclusion criteria were patients who died of sepsis. Antibiotics analyzed using the DIH $25^{\text {th }}$ edition 2016, IONI 2014, Tata Laksana Sepsis Pada Anak IDAI 2016, Neofax 2014, Kepmenkes PNPK Tata Laksana Sepsis 2017, PPK RS, and SHC Antimicrobial Dosing 2017. Based on data from 108 patients who fulfilled the inclusion criteria obtained results right indication 100\%, right patient $97.22 \%$, right drug $90.74 \%$, and the right dose $48.15 \%$. The most used antibiotic was a combination of ampicillin and gentamicin (41.67\%), while the single antibiotic was ceftriaxone (12.96\%).

Keywords: antibiotic, sepsis, inpatient
\end{abstract}

\section{PENDAHULUAN}

Sepsis didefinisikan sebagai disfungsi organ yang mengancam kehidupan yang disebabkan oleh disregulasi respons tubuh terhadap infeksi. Syok septik didefinisikan sebagai bagian dari sepsis dimana sirkulasi dan metabolik seluler yang abnormal dapat meningkatkan mortalitas secara substansial (Napolitano, 2018). Salah satu penyebab morbiditas dan mortalitas anak di ruang rawat inap dan ruang intensif ialah sepsis dan syok septik sebesar 50-60\%. Angka mortalitas sepsis pada anak di Rumah Sakit Cipto Mangunkusumo (RSCM) mencapai 54\% (Ikatan Dokter Anak Indonesia, 2016). Berdasarkan penelitian Rahmantika et al., (2016) pada pasien pediatri di PICU RSUP X ditemukan bahwa penyakit infeksi bakteri 
terbanyak yang dialami pasien antara lain sepsis dan komplikasi pneumonia dengan sepsis. Penelitian yang dilakukan oleh Estiningsih et al., (2016) pada pasien neonatal di NICU rumah sakit yang sama menunjukkan infeksi bakteri terbanyak yang ditemukan antara lain sepsis $(54,3 \%)$, sepsis dengan pneumonia $(28,3 \%)$, dan pneumonia $(17,4 \%)$. Pada tahun 2012, pada penelitian di ruang intensif RSCM selama satu bulan, diketahui mortalitas sepsis selama perawatan mencapai 47,8\% dan angka mortalitas pada fase dini mencapai 34,7\% (Kepmenkes, 2017).

Pemberian antibiotik dini secara intravena ialah salah satu tata laksana mendasar pada sepsis. Surviving Sepsis Campaign (SSC) menyarankan antibiotik harus diberikan segera dalam waktu satu jam setelah pasien terdiagnosis sepsis untuk mengurangi risiko kematian (Napolitano, 2018). Faktor yang berkaitan dengan efek samping dan kematian pada pasien sepsis ialah inisiasi terapi antibiotik yang tidak tepat dan keterlambatan terapi antibiotik yang tepat. Ketidaktepatan terapi antibiotik empiris terjadi pada $46,5 \%$ kasus dengan kematian $35 \%$ dari keseluruhan kasus (Lueangarun and Leelarasamee, 2012). Keterlambatan pemberian antibiotik berhubungan dengan peningkatan mortalitas di rumah sakit (RS). Sepsis tanpa antibiotik meningkatkan risiko kematian pada pasien syok septik sebesar 7,6\% selama 6 jam pertama (Ferrer et al., 2014).

Terapi antibiotik empiris dimulai dengan antibiotik spektrum luas menunjukkan adanya keefektifan. Penggunaan antibiotik spektrum luas yang lama harus dihindari untuk mencegah infeksi multi-drug-resistant bakteri (Oshima et al., 2015). Resistensi pada sepsis dapat meningkatkan angka kematian sebanyak dua kali lipat (Turnidge, 2003). Penelitian Rukmana (2018) menunjukkan dari 46 pasien sepsis di ICU di RSUD Dr. Moewardi tahun 2016-2017 terdapat 13 kasus (28,3\%) yang sudah rasional. Berdasarkan dampak yang dapat terjadi pada terapi antibiotik yang belum rasional maka diperlukan adanya penelitian tentang ketepatan terapi antibiotik pada pasien sepsis rawat inap RS di Jawa Tengah.

\section{METODE PENELITIAN}

Penelitian ini merupakan penelitian observasional. Pengambilan data dilakukan secara retrospektif. Pengambilan sampel dilakukan secara purposive sampling dengan melihat catatan rekam medis pasien rawat inap RS di Jawa Tengah yang terdiagnosis sepsis pada tahun 2018 yang memenuhi kriteria inklusi dan eksklusi.

\section{Populasi dan sampel}

Populasi pada penelitian ini ialah pasien yang terdiagnosis sepsis rawat inap RS di Jawa Tengah. Sampel yang digunakan pada penelitian ini ialah pasien rawat inap yang terdiagnosis sepsis dan memenuhi kriteria inklusi sebagai berikut: pasien sepsis yang mendapatkan terapi antibiotik, pasien yang memiliki data rekam medis meliputi identitas pasien (nomor rekam medis, nama pasien, jenis kelamin, umur, dan berat badan untuk anak); diagnosis; karakteristik obat (nama obat, besaran dosis, frekuensi, durasi, dan rute); dan data laboratorium (kultur bakteri, bilirubin, AST, ALT, dan serum kreatinin) jika ada. Sedangkan kriteria eksklusi pada penelitian yaitu pasien sepsis yang meninggal dunia.

\section{Alat dan Bahan}

Alat yang digunakan pada penelitian ini ialah DIH 25 $5^{\text {th }}$ edition 2016 (American Pharmacist Association, 2016), IONI 2014, Tata Laksana Sepsis Pada Anak IDAI 2016, Neofax 2014, Kepmenkes PNPK Tata Laksana Sepsis 2017, PPK RS, dan SHC Antimicrobial Dosing 2017. Bahan yang digunakan pada penelitian ini ialah catatan rekam medis pasien yang terdiagnosis sepsis rawat inap RS di Jawa Tengah.

\section{Analisis Data}

Data dianalisis menggunakan metode deskriptif berdasarkan pedoman yang digunakan untuk mengetahui ketepatan terapi antibiotik dilihat berdasarkan besarnya persentase dengan masing-masing rumus sebagai berikut: 
Tepat indikasi:

$\frac{\text { Jumlah pasien tepat indikasi }}{\text { Banyaknya pasien dalam penelitian }} \times 100 \%$

Tepat pasien:

$\frac{\text { Jumlah pasien tepat pasien }}{\text { Banyaknya pasien dalam penelitian }} \times 100 \%$

Tepat obat:

$\frac{\text { Jumlah pasien tepat obat }}{\text { Banyaknya pasien dalam penelitian }} \times 100 \%$

Tepat dosis:

Jumlah pasien tepat dosis

Banyaknya pasien dalam penelitian $\times 100 \%$

\section{HASIL DAN PEMBAHASAN}

Populasi pasien sepsis rawat inap RS di Jawa Tengah ialah 476 pasien. Pasien sepsis yang memenuhi kriteria inklusi sebanyak 108 pasien. Pasien yang tereksklusi sebanyak 368 pasien, dikarenakan 229 pasien meninggal dunia, 139 pasien tidak memiliki data tidak lengkap.

\section{Karakteristik Pasien}

Pada tabel 1, dapat diketahui bahwa jenis kelamin pasien sepsis rawat inap RS di Jawa Tengah yang terbanyak ialah laki-laki dengan persentase $64,81 \%$, sedangkan perempuan 35,19\%. Laki-laki memiliki tingkat prevalensi sepsis yang lebih tinggi jika dibandingkan dengan perempuan (van Vught et al., 2017).
Hal ini dapat terjadi karena adanya perbedaan respons imun antara laki-laki dan perempuan. Perempuan memiliki respons imun yang lebih baik dibanding laki-laki karena perempuan memiliki kadar hormon estrogen yang lebih tinggi. Hormon estrogen berperan dalam meningkatkan respons imun adaptif. Jumlah Tumor Necrosis Factor (TNF) pada perempuan juga lebih tinggi dibanding lakilaki. TNF berperan sebagai sitokin dalam respons inflamasi terhadap infeksi (Astutik et al., 2017). Meskipun banyak penelitian yang melaporkan bahwa laki-laki lebih rentan terkena sepsis, literatur yang membahas mengenai hubungan antara jenis kelamin dan angka kematian sepsis masih bervariasi (van Vught et al., 2017).

Kelompok usia pasien sepsis pada penelitian ini didominasi oleh kelompok pediatri. Faktor yang berpengaruh dalam mortalitas sepsis pada anak antara lain faktor tubuh pasien, mikroorganisme penyebab, serta tata laksana yang diberikan. Faktor penting lain yang dapat menentukan luaran pada sepsis ialah status imun pasien. Sistem imun pada anak belum sepenuhnya matang sehingga kemampuan tubuh membunuh patogen juga rendah (Saraswati et al., 2014)

Tabel 1. Karakteristik pasien sepsis rawat inap RS di Jawa Tengah

\begin{tabular}{lcc}
\hline Karakteristik & Jumlah Pasien & Persentase (n=108) \\
\hline Jenis Kelamin & & \\
Laki-laki & 70 & $64,81 \%$ \\
Perempuan & 38 & $35,19 \%$ \\
\hline Kelompok Usia & & \\
Neonatus (0-1 bulan) & 64 & $59,26 \%$ \\
Bayi (> 1 bulan-1 tahun) & 4 & $3,70 \%$ \\
Anak-anak muda (2-5 tahun) & 1 & $0,93 \%$ \\
Anak-anak (6-11 tahun) & 1 & $0,93 \%$ \\
Remaja (12-18 tahun) & - & - \\
Dewasa (19-44 tahun) & 7 & $6,48 \%$ \\
Usia pertengahan (45-59 tahun) & 11 & $10,19 \%$ \\
Lanjut usia (60-74 tahun) & 15 & $13,89 \%$ \\
Lanjut usia tua (75-90 tahun) & 5 & $4,63 \%$ \\
\hline
\end{tabular}

\section{Penyakit Penyerta}

Penyakit penyerta pasien sepsis yang terbanyak ialah jaundice pada pasien pediatri yaitu 45 pasien (41,67\%). Berdasarkan penelitian Najib et al., (2013) faktor risiko bayi mengalami jaundice akibat adanya hiperbilirubinemia ialah sepsis. Hal ini dipertegas dengan penelitian yang dilakukan oleh Halisanti (2017) di RSUD Kabupaten Karanganyar tahun 2016 bahwa terdapat 
hubungan yang signifikan antara neonatus yang mengalami sepsis dengan terjadinya jaundice. Jaundice dapat terjadi karena adanya produksi bilirubin yang berlebihan, sedangkan bayi belum mampu mengeluarkan produksi bilirubin secara maksimal (Tazami et al., 2013).

Penyakit penyerta lainnya yang terdapat pada pasien sepsis yaitu kondisi imunodefisiensi. Pada kelompok pediatri sistem imunitas belum sepenuhnya matang sehingga kemampuan tubuh membunuh patogen juga rendah. Faktor penting yang menentukan luaran pada sepsis ialah status imun pasien. Respons pasien terhadap sepsis berkaitan pula terhadap kematangan sistem imunitas. Imunodefisiensi selain ditemukan pada pediatri, dapat pula dijumpai pada kondisi malnutrisi, penyakit kronis, luka bakar, atau penyakit keganasan (Saraswati et al., 2014). Acute Renal Failure (ARF) paling banyak terjadi pada pasien sepsis dewasa dan geriatri yaitu sebanyak 14 pasien $(12,96 \%)$. ARF merupakan bagian dari sindrom disfungsi multi-organ pada sepsis berat dan syok septik. Pasien ARF dengan sepsis berat dilaporkan memiliki angka mortalitas hingga $70 \%$, sedangkan angka mortalitas ARF tanpa sepsis ialah 40-45\% (Oppert et al., 2008). Disfungsi awal ginjal selama sepsis dapat terjadi karena stres bio-energetik dari sel epitel tubular sebagai respons terhadap sinyal inflamasi yang dihasilkan oleh disfungsi mikrovaskular peritubular (Zarbock et al., 2014).

\section{Karakteristik Hasil Kultur Bakteri}

Beberapa pasien sepsis memiliki hasil kultur bakteri. Jenis bakteri penyebab sepsis terbanyak pada pasien sepsis RS di Jawa Tengah ialah bakteri gram negatif.

Tabel 2. Karakteristik hasil kultur bakteri pasien sepsis rawat inap RS di Jawa tengah

\begin{tabular}{llcc}
\hline & Nama Bakteri & Jumlah Pasien & Persentase $(\mathrm{n}=108)$ \\
\hline Bakteri gram negatif & Escherichia coli & 3 & $2,78 \%$ \\
& Enterobacter cloacae & 2 & $1,85 \%$ \\
& Klebsiella pneumoniae & 1 & $0,93 \%$ \\
& Stenotrophomonas maltophilin & 1 & $0,93 \%$ \\
\hline Bakteri gram positif & Staphylococcus aureus & 2 & $1,85 \%$ \\
\hline Tidak ada kultur & - & 99 & $91,66 \%$ \\
\hline
\end{tabular}

Bakteri gram negatif terbanyak ialah Escherichia coli $(2,78 \%)$ dan bakteri gram positif ialah Staphylococcus aureus (1,85\%) (Tabel 2). Hal ini sejalan dengan penelitian yang dilakukan oleh Abdullah et al., (2015) bahwa bakteri gram negatif yang paling sering menyebabkan sepsis ialah Escherichia coli dan bakteri gram positif yang paling sering menyebabkan sepsis ialah Staphylococcus aureus. Berdasarkan etiologi sepsis, bakteri gram negatif memang menjadi penyebab paling sering yaitu sekitar 60-70\% Kepmenkes, 2017). Namun, di negara maju didapatkan hasil yang berlawanan, penyebab sepsis terutama sepsis neonatorum awitan dini paling sering disebabkan oleh bakteri gram positif (Kardana, 2011). Perbedaan ini dapat terjadi karena pola bakteri penyebab sepsis berbeda-beda antar negara dan selalu berubah dari waktu ke waktu. Perbedaan pola bakteri ini juga terjadi di negara berkembang, meskipun rata-rata penyebab utama dari sepsis neonatorum paling banyak adalah bakteri gram negatif (Haryani and Apriyanti, 2016).

\section{Karakteristik Pengobatan}

a. Terapi Antibiotik

Antibiotik perlu diberikan segera setelah diagnosis sepsis ditegakkan. Pemberian antibiotik diberikan secara deeskalasi, yaitu diawali dengan pemberian antibiotik empiris kemudian dihentikan atau disesuaikan dengan respons klinis atau hasil kultur. Pemberian antibiotik empiris dapat diberikan dengan antibiotik tunggal maupun kombinasi sesuai spektrum bakteri penyebab sepsis (Kepmenkes, 2017). Antibiotik untuk terapi pasien sepsis RS di Jawa tengah diberikan secara tunggal maupun kombinasi (Tabel 3). 
Tabel 3. Karakteristik terapi antibiotik pasien sepsis rawat inap RS di Jawa tengah

\begin{tabular}{llccc}
\hline & \multirow{2}{*}{ Numgal Antibiotik } & \multicolumn{2}{c}{ Jumlah Pasien } & $\begin{array}{c}\text { Persentase } \\
(\mathrm{n}=108)\end{array}$ \\
\cline { 3 - 4 } & Inj. Ceftriaxone & Pediatri & Dewasa dan Geriatri & $12,96 \%$ \\
& Inj. Ceftazidime & 2 & 5 & $6,48 \%$ \\
& Inj. Cefoperazone & - & 5 & $4,63 \%$ \\
& Inj. Ampicillin-sulbactam & 3 & - & $2,78 \%$ \\
& Inj. Cefoperazone-sulbactam & - & 3 & $2,78 \%$ \\
& Inj. Ciprofloxacin & 2 & 1 & $2,78 \%$ \\
& Inj. Meropenem & - & 3 & $2,78 \%$ \\
& Inj. Ampicillin & 2 & - & $1,85 \%$ \\
& Inj. Cefotaxime & 1 & 1 & $1,85 \%$ \\
& Inj. Levofloxacin & 1 & 1 & $0,85 \%$ \\
& Cefixime tablet & - & 1 & $0,93 \%$ \\
Clindamycin tablet & - & 1 & $0,93 \%$ \\
\hline Kombinasi & Inj. Ampicillin + Inj. Gentamicin & 45 & - & $41,67 \%$ \\
& Inj. Ampicillin-sulbactam + Inj. Amikacin & 10 & - & $9,23 \%$ \\
Inj. Cefotaxime + Inj. Amikacin & 2 & - & $1,85 \%$ \\
Inj. Ampicillin-sulbactam + Inj. Gentamicin & 1 & - & $0,93 \%$ \\
& Inj. Ceftazidime + Inj. Levofloxacin & - & 1 & $0,93 \%$ \\
Inj. Ceftriaxone + Cotrimoxazole tablet & - & 1 & $0,93 \%$ \\
Inj. Ceftriaxone + Inj. Levofloxacin & - & 1 & $0,93 \%$ \\
Inj. Ciprofloxacin + Inj. Cefoperazone & - & 1 & $0,93 \%$ \\
\hline
\end{tabular}

Jenis antibiotik tunggal yang banyak digunakan pasien sepsis rawat inap RS di Jawa Tengah ialah antibiotik sefalosporin generasi ketiga yaitu ceftriaxone dengan persentase $12,96 \%$, sedangkan antibiotik kombinasi yang paling banyak digunakan ialah kombinasi ampicillin dan gentamicin dengan persentase $41,67 \%$ (Tabel 3). Sefalosporin generasi ketiga memiliki aktivitas terhadap bakteri gram negatif yang lebih luas dibandingkan sefalosporin generasi kedua. Cefoperazone, cefotaxime, ceftazidime, ceftriaxone, dan cefixime termasuk ke dalam antibiotik golongan sefalosporin generasi ketiga. Ceftazidime dan cefoperazone ialah antibiotik yang aktif terhadap $P$. aeruginosa. Antibiotik golongan karbapenem memiliki mekanisme kerja mencegah pembentukan dinding sel bakteri. Karbapenem diindikasikan untuk infeksi bakteri yang serius seperti pneumonia dan sepsis (Deck and Winston, 2012).

Antibiotik aminoglikosida pada terapi sepsis sering dikombinasikan dengan antibiotik golongan lain yang memiliki mekanisme kerja menghambat dinding sel bakteri seperti $\beta$-laktam. Kombinasi ini digunakan terutama pada terapi sepsis yang bertujuan untuk memperluas aktivitas spektrum empiris dari regimen antibiotik sehingga dapat dipastikan setidaknya ada satu antibiotik yang aktif melawan patogen yang dicurigai (MacDougall and Chambers, 2011). b. Terapi Suportif

Terapi suportif yang banyak diberikan pada pasien sepsis rawat inap RS di Jawa Tengah adalah cairan elektrolit yaitu 53 pasien $(49,07 \%)$. Selain itu, analgetik antipiretik dan anti tukak sebanyak 44 pasien (40,74\%). Cairan elektrolit yang banyak diberikan, salah satunya infus $\mathrm{NaCl} 0,9 \%$ yang merupakan terapi penunjang pada sepsis. Pemberian infus $\mathrm{NaCl} 0,9 \%$ bertujuan untuk resusitasi cairan pada pasien. Penggantian cairan dapat memperbaiki fungsi jantung dan hantaran oksigen sehingga dapat meningkatkan perfusi jaringan dan menghentikan metabolisme anaerob (Kepmenkes, 2017).

Analgetik antipiretik diberikan pada pasien sepsis karena lebih dari $90 \%$ pasien sepsis mengalami demam saat diagnosis. Paracetamol secara signifikan dapat menurunkan lama perawatan intensif dan angka mortalitas di rumah sakit. Paracetamol tidak dapat meningkatkan luaran pada pasien sepsis tetapi dapat memperpanjang kualitas hidup pasien (Chiumello et al., 2017). 
Pada pasien sepsis direkomendasikan juga pemberian terapi profilaksis stress ulcer. Terapi ini hanya direkomendasikan untuk pasien sepsis yang memiliki risiko perdarahan gastrointestinal. Golongan Proton Pump Inhibitor (PPI) atau golongan Histamine-2Receptor Antagonist $\left(\mathrm{H}_{2} \mathrm{RA}\right)$ merupakan anti tukak yang direkomendasikan (Rhodes et al., 2017).

\section{Ketepatan Antibiotik}

a. Tepat indikasi

Tepat indikasi ialah antibiotik yang digunakan harus sesuai dengan diagnosis dokter yang tercantum pada rekam medik yaitu sepsis. Pada penelitian ini, semua pasien sepsis rawat inap RS di Jawa Tengah mendapatkan antibiotik, sehingga dapat disimpulkan bahwa seluruh kasus tepat indikasi (100\%).

b. Tepat pasien

Tepat pasien ialah antibiotik yang digunakan sesuai dengan kondisi pasien baik secara fisiologis maupun patologis dan tidak dikontraindikasikan. Hasil pada penelitian ini menunjukkan bahwa beberapa antibiotik yang digunakan oleh pasien sepsis rawat inap RS di Jawa Tengah belum memenuhi ketepatan pasien (Tabel 4).

Tabel 4. Evaluasi ketepatan pasien pada pasien sepsis rawat inap RS di Jawa Tengah

\begin{tabular}{|c|c|c|c|c|}
\hline & \multirow{2}{*}{ Antibiotik } & \multicolumn{2}{|c|}{ Ketepatan Pasien } & \multirow{2}{*}{$\begin{array}{l}\text { Alasan } \\
\text { Ketidaktepatan }\end{array}$} \\
\hline & & Tepat & Tidak Tepat & \\
\hline \multirow[t]{12}{*}{ Tunggal } & Ceftriaxone & 14 & - & \multirow{12}{*}{$\begin{array}{l}\text { Antibiotik kuinolon } \\
\text { dikontraindikasikan } \\
\text { pada anak }<1 \text { tahun }\end{array}$} \\
\hline & Ceftazidime & 7 & - & \\
\hline & Cefoperazone & 5 & - & \\
\hline & Ampicillin-sulbactam & 3 & - & \\
\hline & Cefoperazone-sulbactam & 3 & - & \\
\hline & Ciprofloxacin & 2 & 1 & \\
\hline & Levofloxacin & 1 & 1 & \\
\hline & Meropenem & 3 & - & \\
\hline & Ampicillin & 2 & - & \\
\hline & Cefotaxime & 2 & - & \\
\hline & Cefixime & 1 & - & \\
\hline & Clindamycin & 1 & - & \\
\hline \multirow[t]{10}{*}{ Kombinasi } & Ampicillin + Gentamicin & 45 & - & \multirow{8}{*}{$\begin{array}{l}\text { Cotrimoxazole } \\
\text { kontraindikasi } \\
\text { pada pasien CKD }\end{array}$} \\
\hline & Ampicillin-sulbactam + Amikacin & 10 & - & \\
\hline & Cefotaxime + Amikacin & 2 & - & \\
\hline & Ampicillin-sulbactam + Gentamicin & 1 & - & \\
\hline & Ceftazidime + Levofloxacin & 1 & - & \\
\hline & Ceftriaxone + Cotrimoxazole & - & 1 & \\
\hline & Ceftriaxone + Levofloxacin & 1 & - & \\
\hline & Ciprofloxacin + Cefoperazone & 1 & - & \\
\hline & Total Pasien & 105 & 3 & \\
\hline & Persentase $(n=108)$ & $97,22 \%$ & $2,78 \%$ & \\
\hline
\end{tabular}

Ketepatan pasien dievaluasi berdasarkan pedoman American Pharmacist Association, 2016 (DIH 25 ${ }^{\text {th }}$ edition 2016) dan IONI 2014. Hipersensitivitas dievaluasi berdasarkan data alergi pasien yang terdapat pada rekam medik. Hasil penelitian didapatkan $105(97,22 \%)$ pasien memenuhi parameter tepat pasien (Tabel 4). Pada penelitian ini terdapat pasien berusia 20 hari mendapatkan ciprofloxacin dan pasien berusia 2 bulan mendapatkan levofloxacin, sehingga pemberian kuinolon belum tepat pasien (Tabel 4). Antibiotik golongan kuinolon dikontraindikasikan pada anak-anak dan remaja $<18$ tahun karena dapat menyebabkan artropati pada sendi (Badan POM RI, 2014). Namun, ketika manfaat pengobatan melebihi risiko, pemberian kuinolon diizinkan pada anak di atas 1 tahun 
untuk infeksi berat seperti pada saluran pernapasan dan sistem pencernaan (termasuk demam tifoid) (Baxter et al., 2016).

Cotrimoxazole dikontraindikasikan untuk pasien dengan gagal ginjal dikarenakan menyebabkan nekrosis tubular atau kristaluria, dan mengurangi sekresi tubulus yang menyebabkan peningkatan serum kreatinin tanpa perubahan GFR yang sebenarnya (Eyler and Shvets, 2019). Pada penelitian ini terdapat pasien dengan penyakit penyerta Chronic Kidney Disease (CKD) mendapatkan cotrimoxazole, sehingga tidak tepat pasien (Tabel 4).

c. Tepat obat

Tepat obat ialah antibiotik yang digunakan merupakan drug of choice.
Pedoman yang digunakan untuk mengevaluasi ketepatan obat pada pasien sepsis pediatri yaitu PPK RS di Jawa Tengah dan Tata Laksana Sepsis Pada Anak IDAI 2016.

Ketentuan antibiotik sepsis anak:

1.) Berdasarkan pedoman PPK RS yaitu kombinasi Ampicillin dan Gentamicin. Bila tanda infeksi masih menetap dalam 48 jam dapat diganti dengan kombinasi Cefotaxime dan Gentamicin.

2.) Berdasarkan pedoman tata laksana sepsis pada anak (IDAI 2016), terapi empiris secara umum digunakan Extended spectrum Penicillin \pm Aminoglikosida atau Sefalosporin generasi 3 atau $4 \quad \pm$ Aminoglikosida atau Kuinolon \pm Vancomycin.

Tabel 5. Evaluasi ketepatan obat pasien sepsis pediatri rawat inap RS di Jawa Tengah

\begin{tabular}{|c|c|c|c|c|}
\hline \multirow[t]{2}{*}{ Antibiotik } & \multirow[t]{2}{*}{ Kultur Bakteri dan Uji Sensitivitas } & \multicolumn{2}{|c|}{ Ketepatan Obat } & \multirow{2}{*}{$\begin{array}{l}\text { Alasan } \\
\text { Ketidaktepatan }\end{array}$} \\
\hline & & Tepat & Tidak Tepat & \\
\hline Ampicillin + Gentamicin & - & 45 & - & \\
\hline $\begin{array}{l}\text { Ampicillin-sulbactam }+ \\
\text { Amikacin }\end{array}$ & - & 10 & - & \\
\hline $\begin{array}{l}\text { Ampicillin-sulbactam }+ \\
\text { Gentamicin }\end{array}$ & - & 1 & - & \\
\hline Cefotaxime + Amikacin & - & 2 & - & \\
\hline Ampicillin & - & 2 & - & \\
\hline Ampicillin-sulbactam & - & 3 & - & \\
\hline Cefotaxime & - & 1 & - & \\
\hline Ceftriaxone & - & 1 & - & \\
\hline $\begin{array}{l}\text { Ciprofloxacin, } \\
\text { Ciprofloxacin* }\end{array}$ & $\begin{array}{l}\text { (+) Klebsiella pneumoniae } \\
\text { (S) Amikacin, Amoxiclav, Gentamicin, } \\
\text { Meropenem, Ceftriaxon, Tobramycin, } \\
\text { Levofloxacin,Ciprofloxacin, } \\
\text { Cefadroxil, Cotrimoxazole, Piperacilin- } \\
\text { tazobactam, Cefuroxime } \\
\text { (R) Ampicillin }\end{array}$ & 1 & 1 & $\begin{array}{l}\text { Tidak } \\
\text { kombinasi } \\
\text { dengan } \\
\text { sefalosporin }\end{array}$ \\
\hline Levofloxacin* & $\begin{array}{l}\text { (+) Stenotrophomonas maltophilin } \\
\text { (S) Levofloxacin } \\
\text { (R) Ampicillin Amikacin, Amoxiclav, } \\
\text { Gentamicin, Meropenem, Ceftriaxone, } \\
\text { Tobramycin, Cefepim, Cotrimoxazol, } \\
\text { Cefuroxim }\end{array}$ & 1 & - & \\
\hline $\begin{array}{l}\text { Ceftazidime, } \\
\text { Ceftazidime* }\end{array}$ & $\begin{array}{l}\text { (+) Enterobacter cloacae } \\
\text { (S)Amikacin,Levofloxacin, } \\
\text { Tobramycin } \\
\text { (R) Ampicillin-sulbactam, Cefuroxim }\end{array}$ & 1 & 1 & $\begin{array}{lr}\text { Tidak } & \text { sesuai } \\
\text { dengan } & \text { hasil } \\
\text { kultur } & \end{array}$ \\
\hline Total Pasien & & 68 & 2 & \\
\hline Persentase $(n=108)$ & & $62,96 \%$ & $1,85 \%$ & \\
\hline
\end{tabular}

Keterangan: *Terapi definitif sesuai hasil kultur bakteri 
Tabel 6. Evaluasi ketepatan obat pada pasien sepsis dewasa dan geriatri rawat inap RS di Jawa Tengah

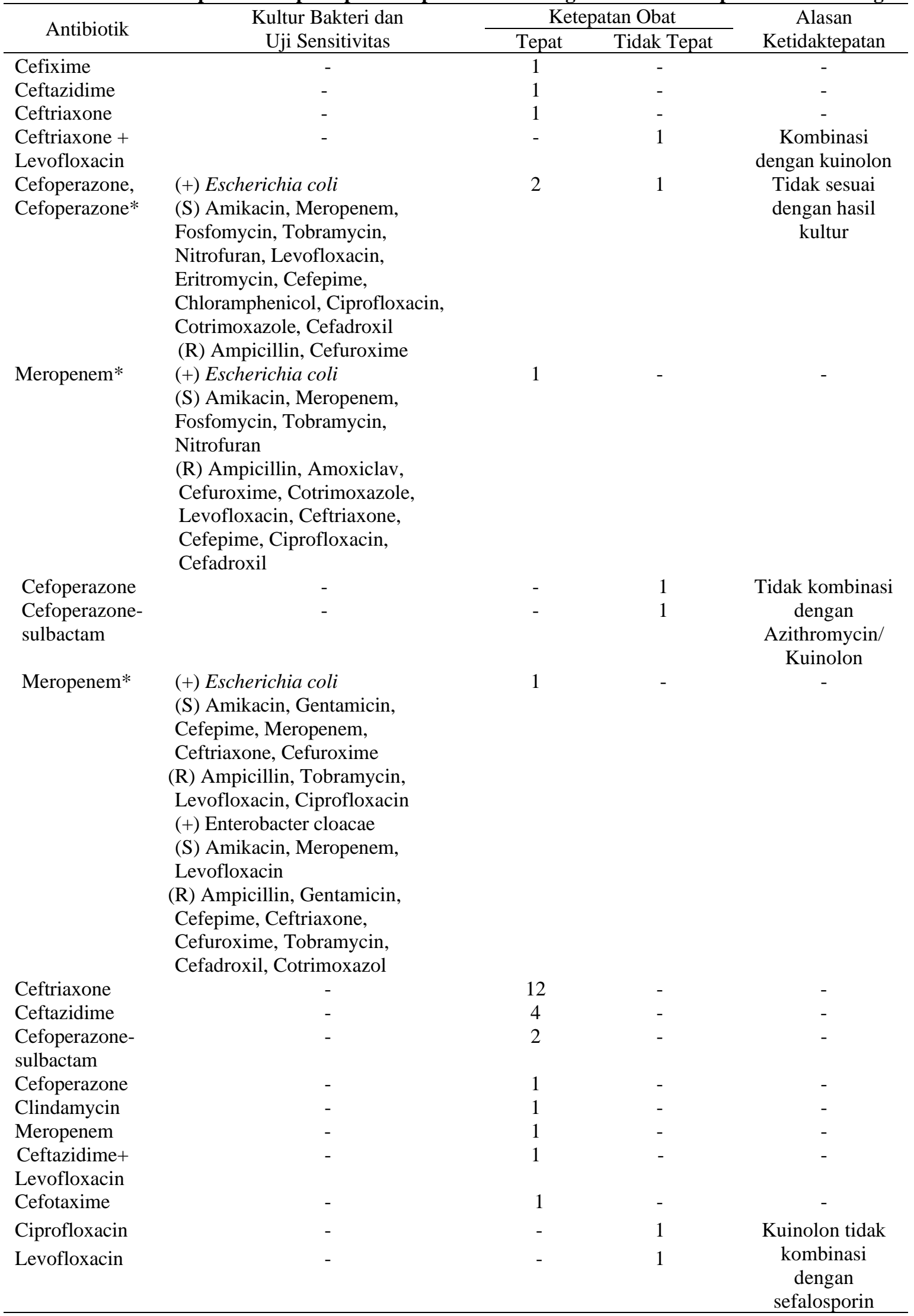


Tabel 6. Lanjutan

\begin{tabular}{|c|c|c|c|c|}
\hline \multirow{2}{*}{ Antibiotik } & \multirow{2}{*}{$\begin{array}{l}\text { Kultur Bakteri dan } \\
\text { Uji Sensitivitas }\end{array}$} & \multicolumn{2}{|c|}{ Ketepatan Obat } & \multirow{2}{*}{$\begin{array}{c}\text { Alasan } \\
\text { Ketidaktepatan }\end{array}$} \\
\hline & & Tepat & Tidak Tepat & \\
\hline $\begin{array}{l}\text { Ciprofloxacin* }{ }^{*}+ \\
\text { Cefoperazone* }\end{array}$ & $\begin{array}{l}\text { (+) Staphylococcus aureus } \\
\text { (S) Eritromycin, Chloramphenicol, } \\
\text { Ciprofloxacin, Cotrimoxazol, } \\
\text { Linezolid, Tetracyclin, Clindamycin } \\
\text { (R) Penicillin }\end{array}$ & - & 1 & $\begin{array}{l}\text { Cefoperazone tidak } \\
\text { sesuai dengan hasil } \\
\text { kultur }\end{array}$ \\
\hline $\begin{array}{l}\text { Ceftriaxone } *+ \\
\text { Cotrimoxazole } *\end{array}$ & $\begin{array}{l}\text { (+) Staphylococcus aureus } \\
\text { (S) Eritromycin, Chloramphenicol, } \\
\text { Cotrimoxazol, Linezolid, } \\
\text { Clindamycin } \\
\text { (R) Penicillin, Tetracyclin, } \\
\text { Ciprofloxacin }\end{array}$ & - & 1 & $\begin{array}{l}\text { Ceftriaxone tidak } \\
\text { sesuai dengan hasil } \\
\text { kultur }\end{array}$ \\
\hline
\end{tabular}

\begin{tabular}{ccc}
\hline Total Pasien & 30 & 8 \\
\hline Persentase (n=108) & $27,78 \%$ & $7,41 \%$ \\
\hline Keterangan: *Terapi definitif sesuai hasil kultur bakteri & &
\end{tabular}

Evaluasi ketepatan obat pada pasien sepsis dewasa dan geriatri berdasarkan pedoman PNPK Tatalaksana sepsis 2017 (Kepmenkes, 2017). Terapi empiris yang digunakan pada pasien dewasa dan geriatri yaitu:

1.) Prinsip secara umum adalah antibiotik spektrum luas seperti Karbapenem atau Sefalosporin generasi 3 atau 4 atau Piperacillin - Tazobactam \pm Kuinolon atau Aminoglikosida. Selain itu, antibiotik bakteriostatik masih tetap dapat digunakan.

2.) Berdasarkan penyakit penyerta

Pasien sepsis dengan ISK dapat diterapi dengan antibiotik Sefalosporin generasi 3 atau Kuinolon atau Karbapenem \pm Aminoglikosida.

Pasien sepsis dengan CAP diberikan antibiotik $\beta$-lactam + Azithromycin atau Kuinolon.

Antibiotik sebagai terapi empiris pada pasien sepsis dapat digunakan pilihan antibiotik secara umum maupun disesuaikan berdasarkan lokasi infeksi bakteri. Antibiotik untuk terapi empiris dapat digunakan secara tunggal maupun dikombinasikan dengan antibiotik golongan lain. Pemilihan antibiotik sebagai terapi definitif disesuaikan dengan hasil kultur bakteri.
Hasil penelitian didapatkan tepat obat pada kelompok pediatri sebanyak 68 pasien $(62,96 \%)$, sedangkan pada pasien dewasa dan geriatri sebanyak 30 pasien $(27,78 \%)$. Berdasarkan hasil tersebut dapat disimpulkan bahwa total jumlah pasien yang tepat obat ialah 98 pasien (90,74\%) (Tabel 5 dan 6). Berdasarkan penelitian Yulianasari (2019) di Instalasi Rawat Inap RSUD dr. Soediran Mangun Sumarso Wonogiri tahun 2016-2018 mengenai evaluasi penggunaan antibiotik secara kualitatif pada pasien sepsis dengan metode Gyssens, dari 34 kasus terdapat $14,71 \%$ antibiotik yang lebih efektif.

Penelitian sejenis yang dilakukan oleh Mentari (2019) di Instalasi Rawat Inap RSUD Pandan Arang Boyolali tahun 2018, dari 72 pasien terdapat $18,10 \%$ antibiotik yang lebih efekif dan 1,3\% antibiotik yang kurang toksik. Pemberian antibiotik secara tepat dan adekuat terbukti dapat menurunkan angka mortalitas pada sepsis maupun syok septik dan harus diberikan segera setelah diagnosis ditegakkan. Pemberian antibiotik yang tidak tepat dilaporkan dapat meningkatkan risiko kematian pada pasien sepsis, cepatnya pertumbuhan bakteri resisten, timbulnya efek samping potensial yang berbahaya bagi pasien, berkaitan pula dengan lamanya perawatan di rumah sakit sehingga 
meningkatkan beban biaya bagi pasien (Budi et al., 2017).

Pertimbangan pemilihan antibiotik harus disesuaikan dengan asal infeksi (komunitas atau nosokomial), lokasi, dan sumber infeksi. Pemberian antibiotik spektrum luas sangat ideal untuk terapi empiris pada sepsis karena dapat mencakup berbagai jenis bakteri. Efikasi monoterapi karbapenem telah terbukti sama dengan kombinasi $\beta$-laktam dengan aminoglikosida. Sefalosporin generasi ketiga dan keempat telah terbukti sama efektifnya dengan kombinasi $\beta$-laktam atau clindamycin dengan aminoglikosida (Blair Sarbacker and Sarbacker, 2012). Sefalosporin generasi ketiga diindikasikan untuk terapi empiris sepsis yang penyebabnya belum diketahui, baik pada pasien imunokompeten maupun dengan gangguan kekebalan (Deck and Winston, 2012).

d. Tepat dosis

Tepat dosis ialah besaran dosis, frekuensi, dan rute antibiotik yang digunakan harus sesuai dengan pedoman. Pedoman untuk mengevaluasi ketepatan dosis pada pasien pediatri menggunakan Tata Laksana Sepsis Pada Anak IDAI 2016 dan Neofax 2014, sedangkan pada pasien dewasa dan geriatri menggunakan SHC Antimicrobial Dosing 2017 dan IONI 2014. Hasil penelitian menunjukkan bahwa dari total 108 pasien, terdapat 52 pasien $(48,15 \%)$ tepat dosis berdasarkan besaran dosis, frekuensi, dan rute antibiotik yang digunakan. Antibiotik yang banyak tidak memenuhi ketepatan dosis yaitu kombinasi ampisillin dan gentamisin pada pasien sepsi anak Sebagian besar karena dosis lebih (Tabel 7).

Penggunaan dosis yang berlebih pada penggunaan obat dapat menyebabkan toksisitas. Beberapa antibiotik seperti cefoperazone, cefoperazone - sulbactam, ceftazidime, ciprofloxacin, dan meropenem memerlukan penyesuaian dosis pada pasien dengan penurunan fungsi ginjal. Sedangkan,
Antibiotik seperti ceftriaxone tidak memerlukan penyesuaian dosis. Akan tetapi, dosis ceftriaxone pada pasien dengan penurunan fungsi ginjal tidak boleh melebihi dari 2 g sehari. Pasien dengan penurunan fungsi ginjal yang tidak dilakukan penyesuaian dosis maka dapat menyebabkan terjadinya peningkatan atau akumulasi dan toksisitas antibiotik dengan cepat. Oleh sebab itu, diperlukan adanya penyesuaian dosis agar keamanan obat dapat meningkat (Hidayati et al., 2016).

Berdasarkan penelitian yang dilakukan oleh Budi et al., (2017) di RS X Yogyakarta selama periode Januari-Desember 2015 mengenai evaluasi Drug Related Problems (DRPs) antibiotik pada pasien sepsis, dari 162 kasus terdapat $7,14 \%$ kasus tidak tepat dosis. Pada penelitian Azaria (2018) mengenai pola penggunaan antibiotik pada pasien sepsis rawat inap penyakit dalam RSUP dr. M. Djamil Padang tahun 2017, didapatkan hasil penggunaan dosis yang tidak sesuai $(17,6 \%)$, interval yang tidak sesuai $(19,7 \%)$, lama pemberian yang tidak sesuai $(42,6 \%)$, dan semua rute sesuai $(100,0 \%)$. Penggunaan dosis yang tidak tepat dapat menyebabkan munculnya patogen yang resisten sehingga penggunaan dosis yang tepat penting untuk mencegah terjadinya resistensi dan menentukan keberhasilan terapi (Wardani, 2017). Resistensi antibiotik dapat memiliki dampak yang besar pada luaran sepsis untuk sebagian besar patogen. Resistensi yang terjadi pada pasien sepsis menyebabkan angka kematian meningkat sekitar dua kali lipat (Turnidge, 2003).

Berdasarkan hasil evaluasi ketepatan indikasi, pasien, obat dan dosis dapat disimpulkan bahwa ketepatan penggunaan antibiotik pada pasien sepsis rawat inap di RS Jawa Tengah yaitu sebesar $48,15 \%$. Akan tetapi, jika dilihat dari hasil klinis pasien pada saat keluar rumah sakit yaitu dalam kondisi membaik. 
Tabel 7. Evaluasi ketepatan dosis pada pasien sepsis rawat inap RS di Jawa Tengah

\begin{tabular}{|c|c|c|c|c|}
\hline \multirow[t]{2}{*}{ Antibiotik } & \multirow[t]{2}{*}{ Pasien } & \multicolumn{2}{|c|}{ Ketepatan Dosis } & \multirow[t]{2}{*}{ Alasan Ketidaktepatan } \\
\hline & & Tepat & Tidak Tepat & \\
\hline Ampicillin & Pediatri & 1 & 1 & OD \\
\hline Ampicillin + Gentamicin & Pediatri & 19 & 26 & $\begin{array}{l}12 \text { resep gentamicin OD, } \\
7 \text { resep ampicillin dan } \\
\text { gentamicin OD, } 5 \text { resep } \\
\text { gentamicin UD, } 1 \text { resep } \\
\text { ampicillin FL dan } \\
\text { gentamicin UD, } 1 \text { resep } \\
\text { ampicillin OD \& FH }\end{array}$ \\
\hline Ampicillin-sulbactam & Pediatri & 2 & 1 & FH \\
\hline Ampicillin-sulbactam + Amikacin & Pediatri & 5 & 5 & $\begin{array}{l}2 \text { resep ampicillin- } \\
\text { sulbactam dan amikacin } \\
\text { OD, } 1 \text { resep amikacin } \\
\text { OD, } 1 \text { resep amikacin } \\
\text { UD, } 1 \text { resep ampicillin } \\
\text { OD FH \& amikacin OD }\end{array}$ \\
\hline $\begin{array}{l}\text { Ampicillin-sulbactam + } \\
\text { Gentamicin }\end{array}$ & Pediatri & 1 & - & - \\
\hline Cefixime & Dewasa & 1 & - & - \\
\hline Cefoperazone & $\begin{array}{c}\text { Dewasa dan } \\
\text { Geriatri }\end{array}$ & 5 & - & - \\
\hline Cefoperazone-sulbactam & $\begin{array}{c}\text { Dewasa dan } \\
\text { Geriatri }\end{array}$ & 3 & - & - \\
\hline \multirow[t]{2}{*}{ Cefotaxime } & Pediatri & - & 1 & UD \\
\hline & Geriatri & 1 & - & - \\
\hline Cefotaxime + Amikacin & Pediatri & 1 & 1 & $\begin{array}{ll}\text { Cefotaxime } & \text { dan } \\
\text { amikacin UD } & \end{array}$ \\
\hline \multirow[t]{2}{*}{ Ceftazidime } & Pediatri & - & 2 & $\begin{array}{l}1 \text { resep UD, } \\
1 \text { resep UD dan FH }\end{array}$ \\
\hline & $\begin{array}{c}\text { Dewasa dan } \\
\text { Geriatri }\end{array}$ & 3 & 2 & $\begin{array}{l}1 \text { resep FL, } 1 \text { resep UD } \\
\text { dan FH }\end{array}$ \\
\hline Ceftazidime + Levofloxacin & Dewasa & 1 & - & - \\
\hline \multirow[t]{2}{*}{ Ceftriaxone } & Pediatri & 1 & - & - \\
\hline & $\begin{array}{c}\text { Dewasa dan } \\
\text { Geriatri }\end{array}$ & 2 & 11 & $\mathrm{FH}$ \\
\hline Ceftriaxone + Cotrimoxazole & Dewasa & - & 1 & Ceftriaxone FH \\
\hline Ceftriaxone + Levofloxacin & Dewasa & 1 & - & - \\
\hline \multirow[t]{2}{*}{ Ciprofloxacin } & Pediatri & 1 & 1 & UD dan FH \\
\hline & Geriatri & - & 1 & UD dan FH \\
\hline Ciprofloxacin + Cefoperazone & Dewasa & 1 & - & - \\
\hline Clindamycin & Dewasa & - & 1 & FL \\
\hline \multirow[t]{2}{*}{ Levofloxacin } & Pediatri & - & 1 & FL \\
\hline & Dewasa & 1 & - & - \\
\hline Meropenem & $\begin{array}{c}\text { Dewasa dan } \\
\text { Geriatri }\end{array}$ & 2 & 1 & $\mathrm{FH}$ \\
\hline Total Pasien & & 52 & 56 & \\
\hline Persentase $(\mathrm{n}=108)$ & & $48,15 \%$ & $51,85 \%$ & \\
\hline
\end{tabular}

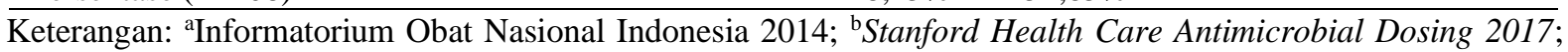
'Neofax 2014; ' Tata Laksana Sepsis Pada Anak IDAI 2016; UD: Underdose; OD: Overdose; FL: Frequency Low; FH: Frequency High 


\section{KESIMPULAN}

Antibiotik tunggal yang paling banyak digunakan untuk terapi sepsis rawat inap RS di Jawa Tengah ialah antibiotik golongan sefalosporin generasi ketiga yaitu ceftriaxone dengan persentase $12,96 \%$. Sedangkan untuk antibiotik kombinasi yang paling banyak digunakan ialah ampicillin dan gentamicin dengan persentase $41,67 \%$. Hasil analisis ketepatan terapi antibiotik didapatkan tepat indikasi sebanyak $100 \%$, tepat pasien sebanyak $97,22 \%$, tepat obat sebanyak $90,74 \%$, dan tepat dosis sebanyak $48,15 \%$. Semua pasien pulang dalam kondisi membaik.

\section{Daftar Pustaka}

Abdullah, Ramatillah D.L. and Eff A.R., 2015. Drug Related Problems that Occurred in Patient Sepsis Macrovascular Disease Complications General Hospital Treatment Room Central of the Army (Army Hospital) Gatot Subroto. Global Journal of Medical Research, 15 (3), $10-14$.

American Pharmacist Association, 2016. Drug Information Handbook: A Clinically Relevant Resource for All Healthcare Proffessionals $25^{\text {th }}$ Edition. Lexicomp. Philadelphia.

Astutik A.W., Annisa N., Rusli R. and Ibrahim A., 2017. Kajian Kesesuaian Pemilihan Antibiotik Empiris pada Pasien Sepsis di Instalasi Rawat Inap RSUD Abdul Wahab Sjahranie Samarinda. Proceeding of the $5^{\text {th }}$ Mulawarman Pharmaceuticals Conferences Fakultas Farmasi Universitas Mulawarman Samarinda, pp. 38-47.

Azaria A., 2018. Pola Penggunaan Antibiotik pada Pasien Sepsis Rawat Inap Penyakit Dalam RSUP dr. M. Djamil Padang Tahun 2017. Skripsi. Fakultas Kedokteran. Universitas Andalas. Padang.

Baxter K., Towers K., Fowlie K., Patel H., McFarlane A.M.G., Callachand N., Corbett T.F., Donnelly J., Villén B.G. and Hossin B., 2016. BNF for Children September 2016-2017. Pharmaceutical Press. London.

Blair Sarbacker G. and Sarbacker L.C., 2012. Empiric Antimicrobial Management of Sepsis. U.S. Pharmacist, 37 (8).

Badan POM RI, 2014. Informatorium Obat Nasional Indonesia (IONI). Badan Pengawas Obat dan Makanan Republik Indonesia. Jakarta.

Budi S., Ikawati Z., Dwiprahasto I. and Nuryastuti T., 2017. Evaluasi Drug Related Problems (DRPs) Antibiotik pada Pasien Sepsis di Rumah Sakit di Yogyakarta. Jurnal Ilmu Kefarmasian Indonesia, 15 (1), 43-49.

Chiumello D., Gotti M. and Vergani G., 2017. Clinical Review: Paracetamol in Fever in Critically Ill Patients - An Update. Journal of Critical Care, 38, 245-252.

Deck D.H. and Winston L.G., 2012. Antibiotik Beta-Laktam \& Aktif Dinding \& Membran Sel Lainnya, Dalam Pendit, B. U., ed. Farmakologi Dasar dan Klinik Edisi 12 Vol. 2. Buku Kedokteran EGC. Jakarta., p. 900.

Estiningsih D., Puspitasari I. and Nuryastuti T., 2016. Identifikasi Infeksi Multidrug-Resistant Organisms (MDRO) pada Pasien yang Dirawat di Bangsal Neonatal Intensive Care Unit (NICU) Rumah Sakit. Jurnal Manajemen dan Pelayanan Farmasi, 6 (3), 243-248.

Eyler R.F. and Shvets K., 2019. Clinical Pharmacology of Antibiotics. Clinical Journal of the American Society of Nephrology, 14, 1080-1090. 
Ferrer R., Martin-Loeches I., Phillips G., Osborn T.M., Townsend S., Dellinger R.P., Artigas A., Schorr C. and Levy M.M., 2014. Empiric Antibiotic Treatment Reduces Mortality in Severe Sepsis and Septic Shock From The First Hour: Results From a Guideline-Based Performance Improvement Program. Critical Care Medicine, 42 (8), 1749-1755.

Halisanti O., 2017. Hubungan Antara Sepsis Neonatorum dengan Terjadinya Ikterus Neonatorum di RSUD Karanganyar. Skripsi. Fakultas Kedokteran. Universitas Muhammadiyah Surakarta. Surakarta.

Haryani S. and Apriyanti Y.F., 2016. Evaluasi Terapi Obat pada Pasien Sepsis Neonatal di Ruang Perinatologi RSUP Fatmawati Januari-Februari Tahun 2016. Journal of Fatmawati Hospital.

Hidayati, Arifin H. and Raveinal, 2016. Kajian Penggunaan Antibiotik pada Pasien Sepsis dengan Gangguan Ginjal. Jurnal Sains Farmasi \& Klinis, 2 (2), 129-137.

Ikatan Dokter Anak Indonesia, 2016. Konsensus Diagnosis dan Tata Laksana Sepsis pada Anak. Badan Penerbit Ikatan Dokter Anak Indonesia. Jakarta.

Kardana I.M., 2011. Pola Kuman dan Sensitifitas Antibiotik di Ruang Perinatologi. Sari Pediatri, 12 (6), 381-385.

Kepmenkes, 2017, Keputusan Menteri Kesehatan Republik Indonesia Nomor HK.01.07/MENKES/342/2017 tentang Pedoman Nasional Pelayanan Kedokteran Tata Laksana Sepsis, Jakarta.

Lueangarun S. and Leelarasamee A., 2012. Impact of Inappropriate Empiric Antimicrobial Therapy on Mortality of Septic Patients with Bacteremia: A Retrospective Study.

MacDougall C. and Chambers H.F., 2011. Aminoglycosides, Dalam Brunton, L. L., ed. Goodman \& Gilman's The Pharmacological Basis of Therapeutics $12^{\text {th }}$ Edition. The McGraw-Hill Companies, Inc., San Diego. p. 1505.

Mentari R., 2019. Evaluasi Penggunaan Antibiotik pada Pasien Sepsis di Instalasi Rawat Inap RSUD Pandan Arang Boyolali Tahun 2018 dengan metode Gyssens. Skripsi. Fakultas Farmasi. Universitas Setia Budi. Surakarta.

Najib K.S., Saki F., Hemmati F. and Inaloo S., 2013. Incidence, Risk Factors and Causes of Severe Neonatal Hyperbilirubinemia in South of Iran (Fars Province). Iranian Red Crescent Medical Journal, 15 (3), 260-263.

Napolitano L.M., 2018. Sepsis 2018: Definitions and Guideline Changes. Surgical Infections, 19 (2), 117-125.

Oppert M., Engel C., Brunkhorst F.-M., Bogatsch H., Reinhart K., Frei U., Eckardt K.-U., Loeffler M. and John S., 2008. Acute Renal Failure in Patients with Severe Sepsis and Septic Shock - A Significant Independent Risk Factor for Mortality: Results from The German Prevalence Study. Nephrology Dialysis Transplantation, 23 (3), 904-909.

Oshima T., Kodama Y., Takahashi W., Hayashi Y., Iwase S., Kurita T., Saito D., Yamaji Y. and Oda S., 2015. Empiric Antibiotic Therapy for Severe Sepsis and Septic Shock, Surgical Infections, 20 (10), 1-7.

Rahmantika F., Sari I.P. and Wahyono D., 2016. Identifikasi Infeksi Multidrug-Resistant Organisms (MDRO) pada Pasien yang Dirawat di Bangsal Pediatric Intensive Care Unit (PICU) RSUP dr. Soeradji Tirtonegoro Klaten Periode Januari 2013-Desember 2015. 
Thesis. Fakultas Farmasi. Universitas Gadjah Mada. Yogyakarta.

Rhodes A., Evans L.E., Alhazzani W., Levy M.M., Antonelli M., Ferrer R., Kumar A., Sevransky J.E., Sprung C.L., Nunnally M.E., Rochwerg B., Rubenfeld G.D., Angus D.C., Annane D., Beale R.J., Bellinghan G.J., et al., 2017. Surviving Sepsis Campaign: International Guidelines for Management of Sepsis and Septic Shock: 2016. Critical Care Medicine, 45 (3), 486-552.

Rukmana R.W., 2018. Evaluasi Rasionalitas Penggunaan Antibiotik pada Pasien Sepsis di Intensive Care Unit (ICU) RSUD dr. Moewardi Surakarta Tahun 2016-2017. Skripsi. Fakultas Farmasi. Universitas Muhammadiyah Surakarta. Surakarta.

Saraswati D.D., Pudjiadi A.H., Djer M.M., Supriyatno B., Syarif D.R. and Kurniati N., 2014. Faktor Risiko yang Berperan pada Mortalitas Sepsis. Sari Pediatri, 15 (5), 281-288.

Stanford Antimicrobial Safety and Sustainability Program, 2017. Stanford Health Care Antimicrobial Dosing Reference Guide. Stanford Medicine. Stanford.

Tazami R.M., Mustarim and Syah S., 2013. Gambaran Faktor Risiko Ikterus Neonatorum pada Neonatus di Ruang Perinatologi RSUD Raden Mattaher Jambi Tahun 2013. Jambi Medical Journal, 1 (1).

Truven Health Analytics, 2014. Micromedex Neofax Essentials 2014. Truven Health Analytics. Greenwood Village.

Turnidge J., 2003. Impact of Antibiotic Resistance on The Treatment of Sepsis. Scandinavian Journal of Infectious Diseases, 35, 677-682.

van Vught L.A., Scicluna B.P., Wiewel M.A., Hoogendijk A.J., Klouwenberg P.M.C.K., Ong D.S.Y., Cremer O.L., Horn J., Franitza M., Toliat M.R., Nürnberg P., Bonten M.M.J., Schultz M.J. and van der Poll T., 2017. Association of Gender With Outcome and Host Response in Critically Ill Sepsis Patients. Critical Care Medicine, 20 (30), 1-9.

Wardani I.S., 2017. Tatalaksana Sepsis Berat pada Pasien Lanjut Usia. Jurnal Kedokteran Unram, 7 (4), 33-39.

Yulianasari M., 2019. Evaluasi Penggunaan Antibiotik secara Kualitatif pada Pasien Sepsis di Instalasi Rawat Inap RSUD dr. Soediran Mangun Sumarso Wonogiri Tahun 2016-2018 dengan metode Gyssens. Skripsi. Fakultas Farmasi. Universitas Setia Budi. Surakarta.

Zarbock A., Gomez H. and Kellum J.A., 2014. Sepsis-Induced Acute Kidney Injury Revisited: Pathophysiology, Prevention and Future Therapies. Current Opinion in Critical Care, 20 (6), 588-595. 